\title{
外付け式層間変形制御装置による中低層建築物の地震応答制御 SEISMIC RESPONSE CONTROL OF MID- AND LOW-RISE BUILDINGS USING EXTERNAL STORY DEFLECTION CONTROL DEVICES
}

\author{
宮 津 裕 次*，曾田 五月也** \\ Yuji MIYAZU and Satsuya SODA
}

\begin{abstract}
This study proposes a seismic response control device which prevents mid- and low-rise buildings from collapsing at specific story under severe earthquake ground motions. The device consists of the frame and the passive damper, which are mounted outside of the building. First, we constructed an analytical model of the device using a mass-spring-damper system and then performed time history seismic response analysis of the four-story steel buildings. We confirmed that the proposed device equalizes deflection of all the stories and reduces the maximum story deflection without excessive increase of the maximum response acceleration.
\end{abstract}

\author{
Keywords : External device, Friction damper, Damage dispersion, Mid- and low-rise building, Steel structure, \\ Severe ground motion \\ 外付け式装置，摩擦ダンパ，損傷分散，中低層建築物，鉄骨構造，過酷な地震動
}

\section{1. はじめに}

2011 年東北地方太平洋沖地震で記録された地震動をはじめとし, 近年日本で発生している大地震においては設計時の想定を大きく上 回る規模の地震動が多く観測されている。これらの地震動は建築物 にとっては「過酷な地震動」であるが，過去に実際に起こっている 限りはそれらに対しても建築物の安全性を確保することが重要であ ると言われている ${ }^{1)}$ 。なお, 本論では地表面の速度が $0.5 \mathrm{~m} / \mathrm{s}$ を超え る地震動を過酷な地震動と定義する。大地震時に崩壊する建築物の 多くは中低層建築物であり, その崩壊形式の大半は特定の層への変 形の集中によるものである。一般に, 建築物の構造部材が設計時の 想定以上の塑性変形に至るような過酷な地震動の入力に対しては, 部材の耐力劣化や $P-\triangle$ 効果等の影響により建築物各層の損傷分布を 任意に制御することは困難と考えられる ${ }^{2)}$ 。一方，地震によって建 築物に入力されるエネルギーを全層でバランスよく吸収させる機構 を建築物に付与することが出来れば，地震時の最大応答変形を低減 でき崩壊を免れられる可能性がある。

このような機構として, 秋山ら ${ }^{3)}$ は, 梁降伏型の骨組においては 梁が塑性化した後も柱が弾性挙動を示すことで損傷を建築物全体に 分散する作用があることに着目し，主構造の柱とは別に常に弾性に とどまる配力柱を有する構造を提案し，その効果について論じてい る。曾田ら ${ }^{4) \sim 8)}$ は, 異なる層に設置した 2 基のオイルダンパをチュ ーブで連結しピストンの動きを連動させることで, オイルダンパに より地震入力エネルギーを吸収すると同時に両層の層間変形を一様 化する効果を発揮する制振構造を提案している。また，和田ら ${ }^{9)}$
既存鉄筋コンクリート造建築物の耐震改修において, 最下層から最 上層まで連層するロッキング壁を建築物外部に設置し，ロッキング 壁と既存建築物との間に鋼材のダンパを配置することで，損傷を全 層に分散しつつダンパによるエネルギー吸収を図る方法を提案し実 建築物に適用している。その他にも，鉄骨ラーメン造建築物の柱脚 部分において, 鉄筋コンクリートの基礎梁から 1 層の一定の高さま で鉄筋コンクリートの柱を立ち上げ，その柱と上部の鉄骨柱とを回 転を許容して接合することで，全層において梁降伏を先行させる工 法に関する金田ら ${ }^{10)}$ による研究などがある。

本論は，新築および既存の中低層建築物を対象に，過酷な地震動 の入力に対しても層崩壊を免れることを目的として地震時の各層の 層間変形を一様化する装置を提案し，その力学特性を明らかにする とともに，損傷を建築物全体に分散する効果と設計上の留意点につ いて時刻歴応答解析により明らかにするものである。なお，著者ら は既報 ${ }^{11)}{ }^{12}$ におおいて，2 層木造住宅に同様の装置を適用寸ることの 有用性を解析と実験により明らかにしているが，本論では対象を一 般の多層建築物に拡張して理論を展開している。2 章では, 提案す る装置の概要を述べ，3 章においてその解析モデルをせん断質点系 モデルとして構築する。4 章では, 全層の層間変形を完全に等しく 寸るために装置に要求される抵抗力の上限值を予測する式を導出し, 時刻歴応答解析により予測式の妥当性を検証する。5 章と 6 章では, それぞれせん断質点系モデルと平面フレームモデルを用いた 4 層鉄 骨造建築物の時刻歴地震応答解析を行い，提案する装置を設置した 建築物の耐震性能について検討寸る。
${ }^{*}$ 広島大学大学院工学研究院 助教・博士 (工学)

** 早稲田大学創造理工学部建築学科 教授・工博
Assistant Prof., Graduate School of Engineering, Hiroshima Univ., Dr. Eng.

Prof., Dept. of Architecture, School of Creative Science and Engineering, Waseda Univ., Dr. Eng. 


\section{2. 提案する装置の概要}

提案する装置は, 既存建築物の耐震補強にも適用しやすいことを 意図して外部から施工可能なものとした。図 1 に外付け式層間変形 制御装置（以下，外付け装置と略記）を設置した建築物の模式図を 示す。ある層の柱脚部と柱頭部にピン接合でフレームを取付け, フ レーム先端部と下階の柱脚部との間にダンパを設置する。そうする ことで，3 章で詳述する通りダンパは外付け装置を設置した 2 つの 層の層間変形を同じにしようとする抵抗力を発揮する。なお, ダン パを設置する部分には必ずしもダンパではなく一定の剛性を有する 棒材等を設置することでも両層の層間变形を同一にする効果は得ら れるが，外付け装置の接合部に生じる応力が過大になることを防止 し設計を簡易にする意味では摩擦ダンパやリリーフ機構付のオイル ダンパを使用することが好ましい。また，そうすることでダンパに よるエネルギー吸収も期待できると考えられる。本論では, 力学的 性質の単純さから摩擦ダンパを用いることとして以降の検討を行う。

\section{3. せん断質点系モデルの構築}

図 2(a)に示すように, 外付け装置を $i$ 層と $i+1$ 層の層間変形を一 様化するように設置した場合のせん断質点系の解析モデルを考える。 なお, 以下の定式化では簡単のため建築物の階高は全ての階で等し いものとする。地震時の質点 $i$ の水平变位を $x_{i}$, 外付け装置と柱と のな寸角を $\theta$ とすると, ダンパの変形 $\delta$ は外付け装置のフレームの 変形を無視すれば,

$\delta=\left\{\left(x_{i}-x_{i-1}\right)-\left(x_{i+1}-x_{i}\right)\right\} \sin \theta$

と近似できる。式中の $\left(x_{i}-x_{i-1}\right)$ と $\left(x_{i+1}-x_{i}\right)$ はそれぞれ $i$ 層と $i+1$ 層の 層間変形なので, $\delta$ は外付け装置を設置した両層の層間変形の差に 比例する。次に, 外付け装置から各質点に作用寸る荷重を求める。 簡単のため, ダンパ部分に剛性 $k_{d}$ の線形ばねが設置されている場合 を考えると, 線形ばねの荷重 $F_{d}$ は,

$F_{d}=k_{d}\left\{\left(x_{i}-x_{i-1}\right)-\left(x_{i+1}-x_{i}\right)\right\} \sin \theta$

となる。また, $F_{d}$ によって質点 $i$ に作用する荷重 $F_{i}$ は, 力の釣り合 いから，

$F_{i-1}=F_{d} \sin \theta, \quad F_{i}=-2 F_{d} \sin \theta, \quad F_{i+1}=F_{d} \sin \theta$

と表せるので，式(3)に式(2)を代入すれば,

$\left\{\begin{array}{c}F_{i-1} \\ F_{i} \\ F_{i+1}\end{array}\right\}=-k_{d} \sin ^{2} \theta\left[\begin{array}{rrr}1 & -2 & 1 \\ -2 & 4 & -2 \\ 1 & -2 & 1\end{array}\right]\left\{\begin{array}{c}x_{i-1} \\ x_{i} \\ x_{i+1}\end{array}\right\}$

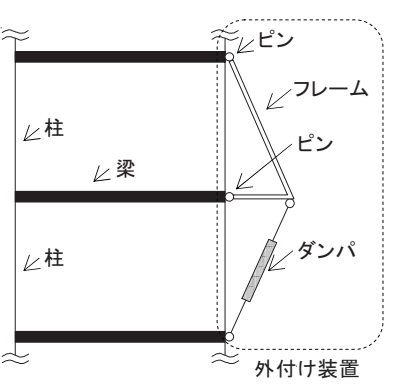

図 1 外付け装置の概要

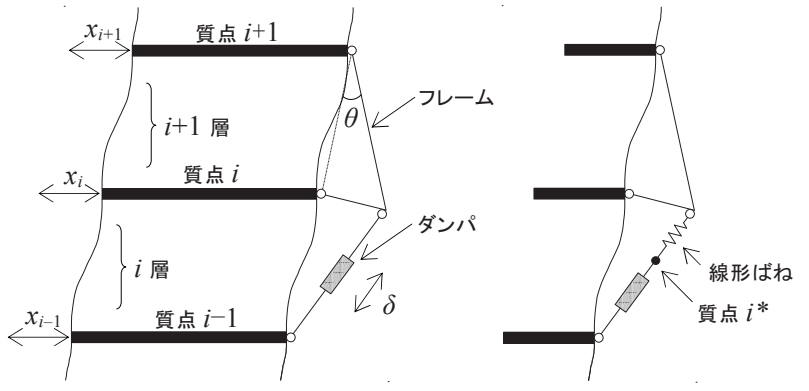

（a）フレームが剛な場合 図 2 外付け装置を設置した建築物の解析モデル
が得られる。

次に, 外付け装置のフレームの変形を考慮した解析モデルを構築

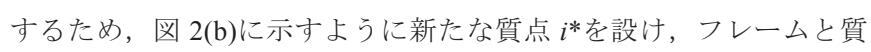
点 $i$ *との間に剛性 $k_{b}$ の線形ばねを配置する。 $k_{b}$ はフレームの剛性を

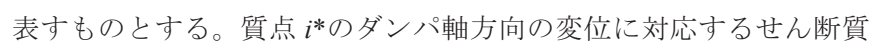
点系モデルの水平方向変位を $x_{i^{*}}$ とすると, ダンパを表すば祆の荷重 $F_{d}$ とフレームを表すばねの荷重 $F_{b}$ はそれぞれ,

$F_{d}=k_{d}\left(x_{i^{*}}-x_{i-1}\right) \sin \theta$

$F_{b}=k_{b}\left(2 x_{i}-x_{i+1}-x_{i^{*}}\right) \sin \theta$

となる。 $F_{d}$ と $F_{b}$ によって各質点に作用する荷重は,

$F_{i-1}=F_{d} \sin \theta, \quad F_{i}=-2 F_{b} \sin \theta, \quad F_{i+1}=F_{b} \sin \theta, \quad F_{i^{*}}=F_{b} \sin \theta$

となるので, 式(5a-b)を式(6)に代入すれば式(7)が得られる。なお, ダンパ部分に線形のオイルダンパが設置されている場合には式(7) の $k_{d}$ を減衰係数に， $k_{d}$ に対応する変位べクトルを速度べクトルに置 き換えればよい。また， ベクトルを増分形で表現すれば，ダンパの 力学特性が非線形の場合にも同様に式(7)が成り立つ。

$\left\{\begin{array}{c}F_{i-1} \\ F_{i} \\ F_{i+1} \\ F_{i^{*}}\end{array}\right\}=-\sin ^{2} \theta\left(k_{d}\left[\begin{array}{rrrr}1 & 0 & 0 & -1 \\ 0 & 0 & 0 & 0 \\ 0 & 0 & 0 & 0 \\ -1 & 0 & 0 & 1\end{array}\right]+k_{b}\left[\begin{array}{rrrr}0 & 0 & 0 & 0 \\ 0 & 4 & -2 & -2 \\ 0 & -2 & 1 & 1 \\ 0 & -2 & 1 & 1\end{array}\right]\right)\left\{\begin{array}{c}x_{i-1} \\ x_{i} \\ x_{i+1} \\ x_{i *}\end{array}\right\}$

\section{4. ダンパの必要抵抗力の上限值予測式 \\ 4.1 予測式の導出}

図 3 に示寸ように全層に外付け装置を設置する $n$ 層建築物におい て，全層の層間変形を完全に等しく寸るために必要となるダンパの 抵抗力の上限值を考える。 $i+1$ 階（質点 $i$ ) の質量を $m_{i}, i$ 層の主構 造の抵抗力を $Q_{i}, i$ 層と $i+1$ 層の層間変形を一様化するように $i$ 層に 設置したダンパの抵抗力を $F_{d i}$, 質点 $i$ の相対加速度を $\ddot{x}_{i}$, 地動加速 度を菂とすれば，質点 $i$ での力の釣り合いは,

$$
m_{i}\left(\ddot{x}_{i}+\ddot{x}_{0}\right)+Q_{i}-Q_{i+1}+\left(2 F_{d i}-F_{d i-1}-F_{d i+1}\right) \sin \theta=0
$$

と表せる。ただし, $F_{d n}=F_{d n+1}=0$ である。

ここで，外付け装置を設置することにより全層の層間変形が完全 に等しくなると仮定すれば, 質点 $i$ の相対加速度は質点 1 の相対加 速度を用いて $\ddot{x}_{i}=i \ddot{x}_{1}$ と表せるので, これを式(8)に代入しさらに未知 数を含む項を左辺に移項すれば,

$i m_{i} \ddot{x}_{1}+\left(2 F_{d i}-F_{d i-1}-F_{d i+1}\right) \sin \theta=Q_{i+1}-Q_{i}-m_{i} \ddot{x}_{0}$ 
となる。同様に全ての質点について力の釣り合いを考えれば, ダン パの抵抗力 $F_{d i}$ と質点 1 の相対加速度 $\ddot{x}_{1}$ を未知数とする $n$ 元の連立一 次方程式が式(10)のように得られる。

$[A]\left\{F_{d}\right\}=\{Q\}-[M]\{1\} \ddot{x}_{0}$

ここで,

$[A]=\left[\begin{array}{cccc:c}2 & -1 & \ddots & 0 & m_{1} \\ -1 & 2 & -1 & \ddots & 2 m_{2} \\ \ddots & \ddots & \ddots & \vdots \\ & -1 & 2 & -1 & (n-2) m_{n-2} \\ & \ddots & -1 & 2 & (n-1) m_{n-1} \\ 0 & & \ddots & -1 & n m_{n}\end{array}\right]$, $\left\{F_{d}\right\}=\left\{\begin{array}{c}F_{d 1} \sin \theta \\ F_{d 2} \sin \theta \\ \vdots \\ F_{d n-2} \sin \theta \\ F_{d n-1} \sin \theta \\ \ddot{x}_{1}\end{array}\right\}$

$\{Q\}=\left\{\begin{array}{c}Q_{2}-Q_{1} \\ Q_{3}-Q_{2} \\ \vdots \\ Q_{n-1}-Q_{n-2} \\ Q_{n}-Q_{n-1} \\ -Q_{n}\end{array}\right\}$

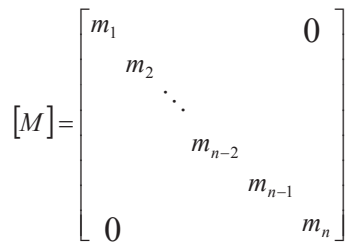

である。式(10)の両辺に左から $[A]^{-1}$ 乗じれば,

$\left\{F_{d}\right\}=[A]^{-1}\left(\{Q\}-[M]\{1\} \ddot{x}_{0}\right)$

となり, 各階の質量と各層の抵抗力および地動加速度が与えられれ ばダンパの抵抗力 $F_{d i}$ が求められる。なお， $F_{d i}$ が最大となるのは, 主構造の全層の抵抗力が最大耐力に達しており, かつ最大の地動加 速度 $\ddot{x}_{0 \max }$ が発生している瞬間と予想される。よって, 全層の層間変 形を完全に等しく寸るために必要な $i$ 層のダンパの抵抗力の上限値 の予測值 $F_{d i l i m}$,

$$
\begin{array}{r}
\left\{F_{d \lim }\right\}=\max \left(\frac{1}{\sin \theta}[A]^{-1}\left(\left\{Q_{\max }\right\}-[M]\{1\} \ddot{x}_{0 \text { max }}\right),\right. \\
\left.\frac{1}{\sin \theta}[A]^{-1}\left(\left\{Q_{\min }\right\}-[M]\{1\} \ddot{x}_{0 \text { max }}\right)\right)
\end{array}
$$

と定式化する。ここで，

$\left.\left.\left\{F_{d \lim }\right\}=\left\{\begin{array}{c}F_{d 1 \lim } \\ F_{d 2 \lim } \\ \vdots \\ F_{d n-2 \lim } \\ F_{d n-1 \lim } \\ \ddot{x}_{1} / \sin \theta\end{array}\right\}, Q_{\max }\right\}=\left\{\begin{array}{c}Q_{2 \max }-Q_{1 \max } \\ Q_{3 \max }-Q_{2 \max } \\ \vdots \\ Q_{n-1 \max }-Q_{n-2 \max } \\ Q_{n \max }-Q_{n-1 \max } \\ -Q_{n \max }\end{array}\right\}, Q_{\min }\right\}=\left\{\begin{array}{c}Q_{2 \min }-Q_{1 \min } \\ Q_{3 \min }-Q_{2 \min } \\ \vdots \\ Q_{n-1 \min }-Q_{n-2 \min } \\ Q_{n \min }-Q_{n-1 \min } \\ -Q_{n \min }\end{array}\right\}$

であり， $Q_{i \max }$ と $Q_{i \min }$ はそれぞれ $i$ 層の変形正側と変形負側の耐力の 最大值とし, 図 4 に示寸抵抗力に対応する。また, max はベクトル の各行ごとに值の大小を比較し大きい方の值を選択する記号とする。

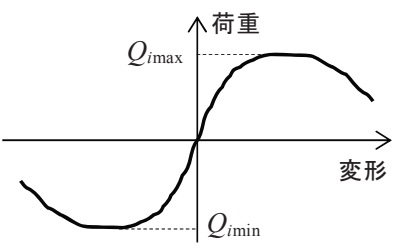

図 $4 i$ 層の荷重変形履歴の骨格曲線と $Q_{i \max }, Q_{i \min }$

\section{2 時刻歴応答解析による予測式の検証}

前節で導出した予測式の妥当性を検証するため, 各階の質量分布 と各層の耐力分布をパラメータとしたせん断多質点系モデルの地震 応答解析を行う。建物モデルには，4 層鉄骨造建築物と 2 層木造建 築物の 2 種類を用いる。鉄骨造モデルの標準モデルは, 各階の質量 を $200 \mathrm{t}$, 弾性 1 次固有周期を $0.4 \mathrm{~s}$ とし, 各層の最大耐力を標準層 せん断力係数 $C_{0}=1.0$, 構造特性係数 $D_{s}=0.3$, 形状係数 $F_{e s}=1.0$, 地震 地域係数 $Z=1.0$ として $A_{i}$ 分布に基づいて計算される必要保有水平耐 力に等しくしたモデルとする。主構造の復元力特性は図 5 に示すト リリニア型とし, 第 2 剛性は初期剛性 $k_{i}$ の 0.25 倍, 第 3 剛性は 0 , 第 1 降伏耐力は最大耐力 $Q_{i}$ の 0.6 倍とした。なお, 各層の剛性の分 布は耐力の分布に相似とした。表 1 には，標準モデルの各層の初期 剛性と最大耐力を示す。

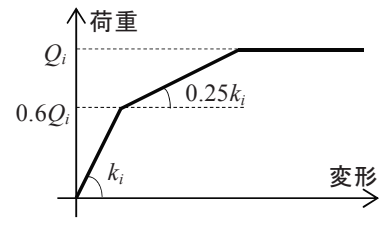

図 5 トリリニア型
表 1 鉄骨造標準モデルの 各層の初期剛性と最大耐力

\begin{tabular}{|c|c|c|}
\hline$i$ & $k_{i}[\mathrm{kN} / \mathrm{m}]$ & $Q_{i}[\mathrm{kN}]$ \\
\hline 4 & 206469 & 962 \\
\hline 3 & 336243 & 1567 \\
\hline 2 & 434232 & 2024 \\
\hline 1 & 504703 & 2352 \\
\hline
\end{tabular}

木造モデルでは, 2 階と R 階の質量をそれぞれ $11.9 \mathrm{t}, 10.29 \mathrm{t}$ とし, 各層の最大耐力を $C_{0}=1.0, D_{s}=0.6, F_{e s}=1.0, Z=1.0$ として $A_{i}$ 分布に 従って求まる必要保有水平耐力と等しくしたものを標準モデルとす る。復元力特性には Extended normalized characteristic loop (ENCL) モデル ${ }^{13)}$ を用い, 構造用合板を張った木造軸組壁の履歴形状を模擬 寸るようにモデルパラメータ $A, B, n_{1}, n_{2}$ を設定した。図 6 には用い る ENCL モデルの荷重変形履歴を, 表 2 には ENCL モデルのパラメ ータと標準モデルの各層の骨格曲線をそれぞれ示す。表 2 中の $d$ は 層間変形, $Q_{i}$ は各変形における $i$ 層の抵抗力である。なお, 各層の 剛性分布は耐力分布に相似とした。

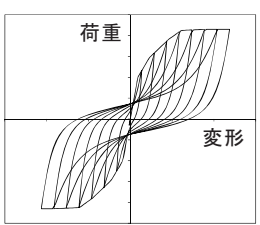

図 6 ENCL モデル
表 2 木造標準モデルの骨格曲線と ENCL モデルのパラメータ
ここでは，鉄骨造モデルと木造モデルのそれぞれについて，質量 分布を標準モデルと等しくし耐力分布を任意に設定した 10 通りの モデルと, 耐力分布を標準モデルと等しくし質量分布を任意に設定 した 10 通りのモデルの合計 20 通りのモデルについて地震応答解析 を行い，式(12)による $F_{d i l i m}$ の予測值の妥当性を検証する。各モデル の質点 $i$ の質量 $m_{i}$ および $i$ 層の最大耐力 $Q_{i}$ は下式により決定した。 $m_{i}=r_{i} \times \sum_{j=1}^{n} m_{j}^{s} \quad, \quad Q_{i}=r_{i} \times \sum_{j=1}^{n} Q_{j}^{s}$ ここで, $m_{j}^{s}$ と $Q_{j}^{s}$ はそれぞれ標準モデルの質点 $j$ の質量と $j$ 層の最大 耐力とし, $n$ は質点数と寸る。また, $r_{i}$ は $[0,1]$ の一様乱数であり, $\sum_{i=1}^{n} r_{i}=1$ 
と規淮化することで, 全質点の質量の総和と全層の最大耐力の総和 が標準モデルと等しくなるようにした。鉄骨造モデルと木造モデル の何れにおいても主構造の減衰は $0 \%$ とし, 骨格曲線は負勾配にな らないものとした。外付け装置の解析モデルには式(4)を用い, 線形 ばねの剛性 $k_{d}$ は全層の層間変形が完全に等しくなるように十分に大 きな値とした。入力地震動は, 1995 年兵庫県南部地震での JR 鷹取 駅観測波 NS 成分の原波（以下，鷹取波と略記）と同地震での神戸 海洋気象台観測波 NS 成分の原波（以下，神戸波と略記）とし，数 值積分は刻み時間を $0.0005 \mathrm{~s}$ として Newmark $\beta$ 法 $(\beta=0.25)$ により 行った。鷹取波と神戸波の最大地動加速度はそれぞれ $6.41 \mathrm{~m} / \mathrm{s}^{2}$ と $8.21 \mathrm{~m} / \mathrm{s}^{2}$ である。

図 7,8 には鉄骨造モデルについて, 図 9 には木造モデルについて, それぞれ質量分布および耐力分布を変化させた各モデルの $F_{d i}$ の最 大応答值と予測值 $F_{d i \mathrm{ilim}}$ の比を示す。なお, 寸べての解析において主 構造は全層で最大耐力に達していること, また全てのモデルにおい て, 最大地動加速度の大きい神戸波を入力波とした場合の方が $F_{d i l i m}$ の值が大きいことを確認している。いずれのモデルにおいても応答 值は予測值と比較して同等あるいは小さい值となっており, 式(12) によってダンパの抵抗力の上限を予測できていることが認められる。

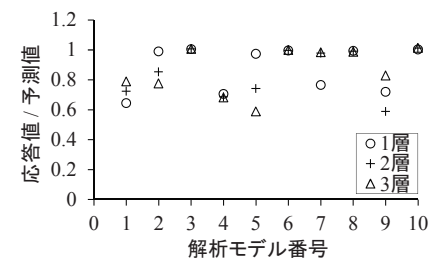

(a) 質量分布を任意

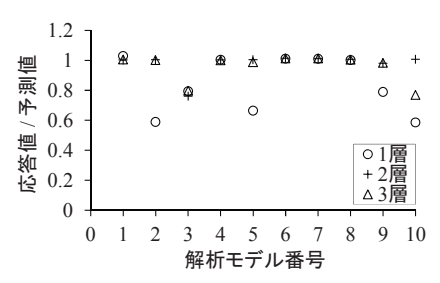

(b) 耐力分布を任意
図 7 鉄骨造モデルの $F_{d i}$ の最大值と予測値 $F_{d i \mathrm{im}}$ の比（鷹取波）

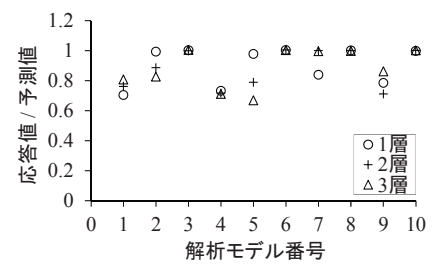

（a）質量分布を任意

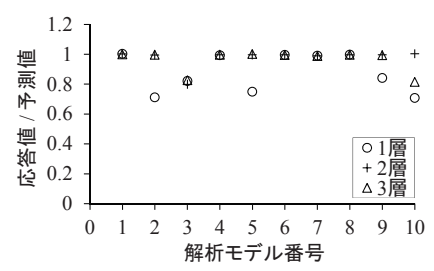

(b) 耐力分布を任意
図 8 鉄骨造モデルの $F_{d i}$ の最大值と予測值 $F_{d i l i m}$ の比（神戸波）

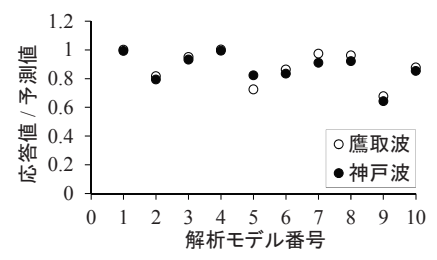

(a) 質量分布を任意

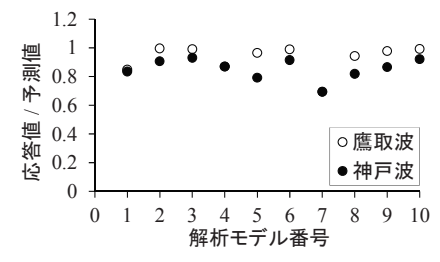

(b) 耐力分布を任意
図 9 木造モデルの $F_{d i}$ の最大値と予測値 $F_{d i l \mathrm{im}}$ の比

\section{5. ダンパの最大抵抗カとフレームの剛性の影響}

\section{1 解析モデルと解析方法}

4 章では, 外付け装置を設置する建築物の各階の質量と各層の最 大耐力, および入力地震動の最大加速度が与えられれば, 全層の層 間変形角を完全に等しくするために必要となるダンパの抵抗力の上 限值を予測できることを示した。建築物の損傷を全層に分散させる
という目標に対しては, 式(12)から計算される予測值 $F_{d i l i m}$ をダンパ の最大抵抗力とすることが理想であるが，実際にはダンパに許容さ れる抵抗力がダンパを設置する周辺の部材の耐力等によって制限さ れる場合もある。また，加速度応答を過大としないことを考慮すれ ば, ダンパの最大抵抗力を $F_{\text {dilim }}$ よりも低い值に設定した方が良いと 判断される場合もあると考えられる。

本章では, ダンパの最大抵抗力が層間変形を一様化する効果およ び加速度応答に与える影響と, 外付け装置のフレームの剛性の影響 について時刻歴応答解析により検討寸ることで, 外付け装置を設置 する建築物の設計にあたって考慮すべき点について考察する。

解析モデルの主構造は, 一般的な仕様の 4 層鉄骨造建築物を想定 し, 各階の質量は $200 \mathrm{t}$, 各層の剛性と耐力は表 3 に示寸 4 種類に設 定した。標準 0.3 は， 4.2 節で使用した標準モデルと同じであり，一 様 0.3 は標準 0.3 と弾性 1 次固有周期が等しく剛性と耐力が全層で 等しいモデルである。標準 0.5 および一様 0.5 は, それぞれ標準 0.3 と一様 0.3 の剛性と耐力を $5 / 3$ 倍したモデルである。復元力特性は 図 5 に示したトリリニア型とした。

\section{表 3 解析モデルの主構造の剛性と耐力}

\begin{tabular}{c|cc|cc|cc|cc}
\hline \multirow{2}{*}{$i$} & \multicolumn{2}{|c|}{ 標準0.3 } & \multicolumn{2}{c|}{ 一様0.3 } & \multicolumn{2}{c|}{ 標準0.5 } & \multicolumn{2}{c}{ 一様0.5 } \\
& $k_{1 i}$ & $Q_{y 2 i}$ & $k_{1 i}$ & $Q_{y 2 i}$ & $k_{1 i}$ & $Q_{y 2 i}$ & $k_{1 i}$ & $Q_{y 2 i}$ \\
& {$[\mathrm{kN} / \mathrm{m}]$} & {$[\mathrm{kN}]$} & {$[\mathrm{kN} / \mathrm{m}]$} & {$[\mathrm{kN}]$} & {$[\mathrm{kN} / \mathrm{m}]$} & {$[\mathrm{kN}]$} & {$[\mathrm{kN} / \mathrm{m}]$} & {$[\mathrm{kN}]$} \\
\hline 4 & 206469 & 962 & 409138 & 2352 & 344184 & 1604 & 682032 & 3921 \\
3 & 336243 & 1567 & 409138 & 2352 & 560518 & 2612 & 682032 & 3921 \\
2 & 434232 & 2024 & 409138 & 2352 & 723866 & 3373 & 682032 & 3921 \\
1 & 504703 & 2352 & 409138 & 2352 & 841339 & 3921 & 682032 & 3921 \\
\hline
\end{tabular}

外付け装置の解析モデルには式(7)を用いる。ダンパ部材には摩擦 ダンパを想定して完全弾塑性型のばねを設置し, ダンパの負担する 最大抵抗力を任意の值に設定する。ここでは $i$ 層と $i+1$ 層の層間変 形を一様化するように $i$ 層に設置したダンパの最大抵抗力を $F_{d i \max }$ とし, 式(12)によって求めたダンパの必要抵抗力の上限值 $F_{\text {dilim }}$ に対 する $F_{d i \max }$ の比を $\alpha$ として $\alpha=0,0.2,0.4,0.6,0.8,1$ の場合について検 討する。 $\alpha=0$ は外付け装置を設置しない場合に対応する。また $i+1$ 層に設置したフレームの剛性を $k_{b i}$ とし， $i$ 層の初期剛性 $k_{1 i}$ に対す る $k_{b i} \sin ^{2} \theta$ の比 $\beta$ をパラメータとした解析も行う。なお， $\alpha$ をパラメ ータとする解析では $\beta$ は十分に大きな值とすることで剛なフレーム とし， $\beta$ をパラメータとする解析では $\alpha=1$ とした。

入力地震動は, 標準 0.3 と一様 0.3 のモデルに対しては鷹取波, 標準 0.5 と一様 0.5 のモデルに対しては 2004 年新潟県中越地震での 川口町観測波 EW 成分の原波（以下，川口波と略記）とした。川口 波の最大加速度は $16.76 \mathrm{~m} / \mathrm{s}^{2}$ である。表 4 には $\alpha=1$ に対応する $F_{d i \max } \sin \theta$ の值を示す。

表 4 各モデルに設置するダンパの最大抵抗力 $[\mathrm{kN}]$

\begin{tabular}{l|c|c|c|c}
\hline & 標準0.3 & 一様0.3 & 標準0.5 & 一様0.5 \\
\hline$F_{d 3 \max } \sin \theta$ & 469 & 1525 & 1186 & 2947 \\
$F_{d 2 \max } \sin \theta$ & 858 & 2110 & 2239 & 4325 \\
$F_{d 1 \max } \sin \theta$ & 906 & 1640 & 2318 & 3541 \\
\hline
\end{tabular}

主構造の減衰は，主構造の初期剛性に対して剛性比例型で $2 \%$ と なるように層間にダッシュポットを設置した。また，P-A 効果を考 慮するため, 


$$
k_{P \Delta i}=-\frac{\sum_{j=i}^{4} m_{j} g}{h_{i}} \quad(i=1,2,3,4)
$$

で計算される剛性 $k_{P \Delta i}$ の線形ばねを $i$ 層に付加した。ここで, $g$ は重 力加速度で $9.8 \mathrm{~m} / \mathrm{s}^{2}, h_{i}$ は $i$ 層の階高で全層 $3.5 \mathrm{~m}$ とした。なお, 式 (12)によって $F_{\text {dilim }}$ を計算する際には, 主構造の減衰と $P$ - $\Delta$ 効果の影 響は無視した。

\section{2 解析結果と考察}

標準 0.3 と一様 0.3 について, $\alpha$ と最大層間変形との関係を図 10 に示す。いずれも $\alpha=1$ においては全層の層間変形がほぼ等しくなっ ており， $F_{d i \mathrm{im}}$ の算出において主構造の減衰と $P$ - $\Delta$ 効果を無視した影 響は認められない。また， $\alpha$ が小さくなるに伴って層間変形の一様 化効果は小さくなる傾向であるが, $\alpha=0.4$ 程度でも大幅な応答低減 を期待できることがわかる。図 11 には, 各層とダンパの累積吸収エ ネルギーを示す。 $\alpha=0$ の場合には地震入力エネルギーの大半を 1 層 で吸収しているが， $\alpha$ の増大に伴って全層でバランスよくエネルギ 一を吸収出来ている。また, 一様 0.3 では $\alpha$ が小さい範囲において 1 層と 2 層の層間変形の差が大きいため, ダンパも一定のエネルギ 一を吸収している。図 12 には，標準 0.3 の $\alpha=0,1$ のそれぞれの場合 について全層の荷重変形履歴を比較して示す。図の縦軸は, 当該層 より上の各階に作用する慣性力の和として求めた層せん断力である 外付け装置を設置した場合にも履歴形状は安定しており, 層せん断 力の大幅な増大は見られない。図 13 には各階の最大応答加速度を示 す。外付け装置を設置した場合でも加速度の増加は小さく耐震性能 としては良い傾向である。

図 14 には, $\alpha=1$ として $\beta$ を変化させた場合の各層の最大層間変形 の変化を示す。変形が集中する 1 層に着目寸れば, $\beta$ と層間変形と の関係は指数関数的な挙動を示すため, $\beta$ が過小な值とならないよ うにフレームの剛性を決定する必要がある。

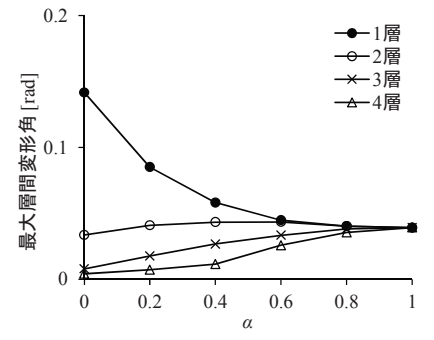

(a) 標準 0.3

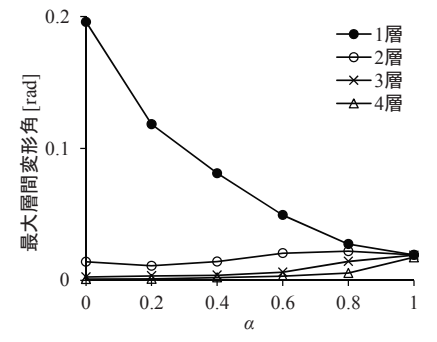

(b) 一様 0.3
図 $10 \alpha$ と最大層間変形角の関係

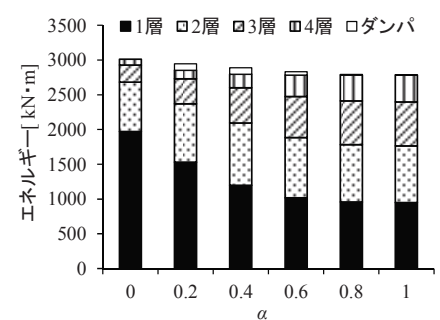

(a) 標準 0.3

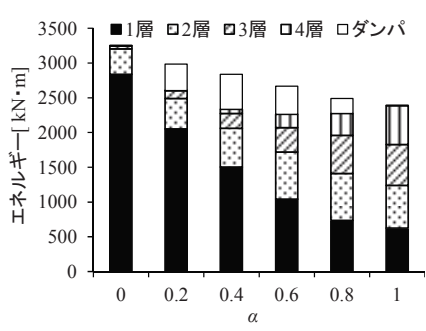

(b) 一様 0.3
図 $11 \alpha$ と各部の累積吸収エネルギーの関係

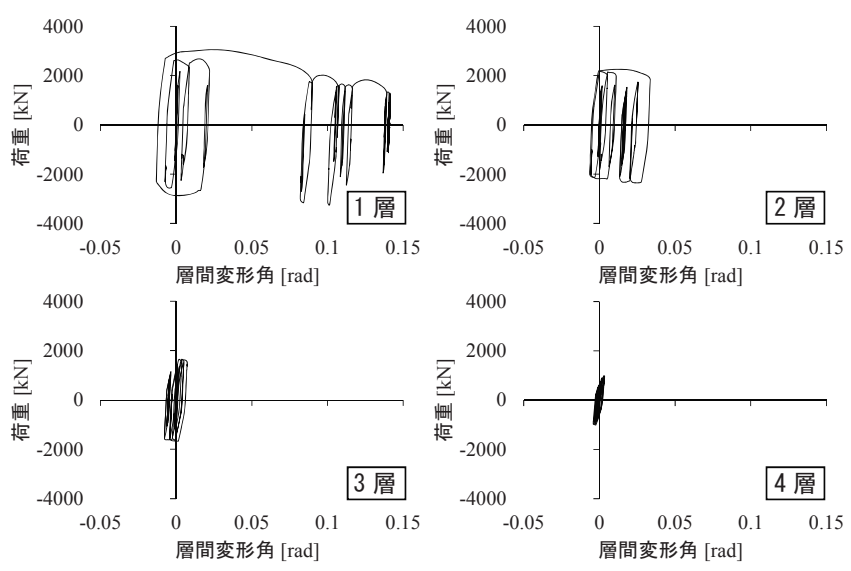

(a) $\alpha=0 （$ 標準 0.3)

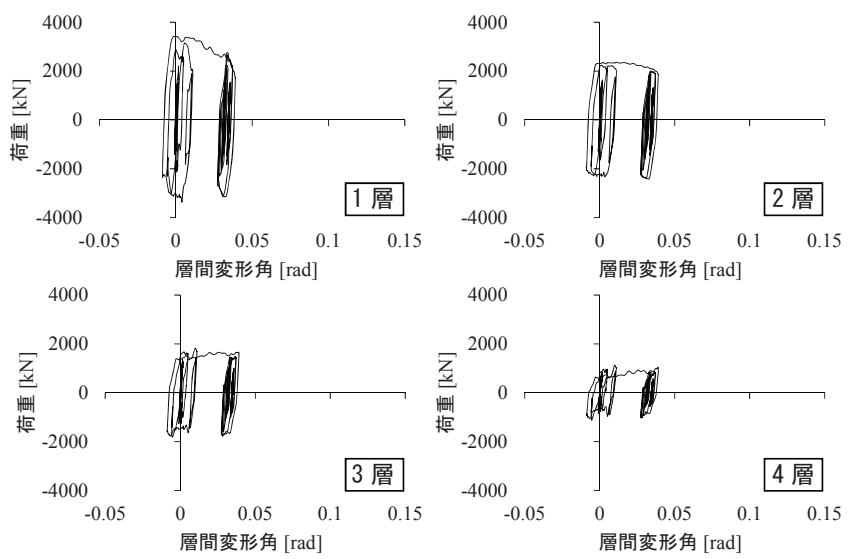

(b) $\alpha=1$ (標準 0.3)

図 12 層の荷重変形履歴

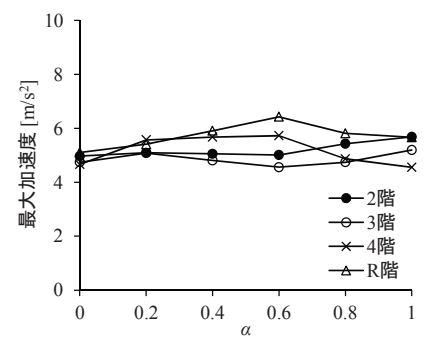

(a) 標準 0.3

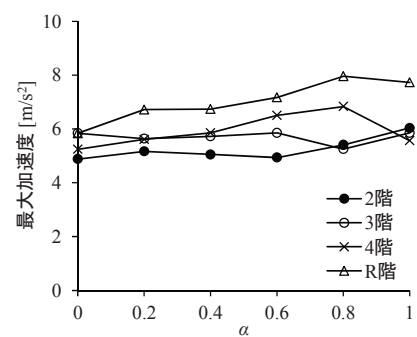

(b) 一様 0.3
図 $13 \alpha$ と最大応答加速度の関係

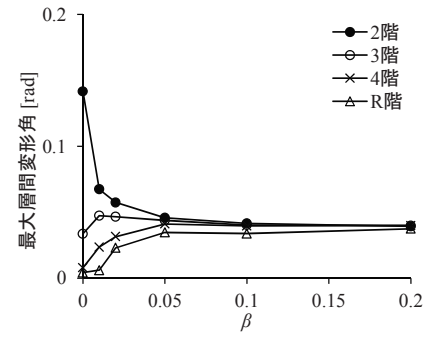

(a) 標準 0.3

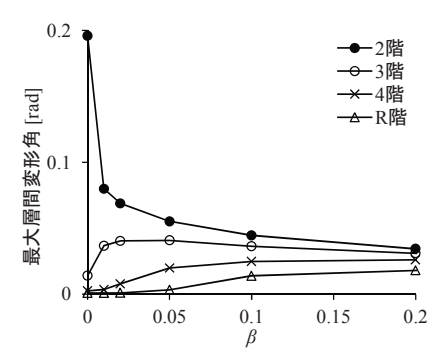

(b) 一様 0.3
図 $14 \beta$ と最大層間変形角の関係

図 15〜18 には, 標準 0.5 と一様 0.5 の解析結果について標準 0.3 , 一様 0.3 の場合と同様に示す。 $\alpha$ と最大層間変形および各部の吸収 エネルギーの関係と, $\beta$ と最大層間変形の関係に関しては, 標準 0.3 
および一様 0.3 の結果と同様の傾向であるが， $\alpha$ と最大応答加速度 の関係については傾向が異なり， $\alpha$ の増大に伴う応答加速度の増大 が顕著である。これは，表 4 に示したように，川口波は最大加速度 が極めて大きいために $F_{d i l i m} \sin \theta か ゙$ 主構造の最大耐力と同程度の大き な值となり, 結果的にダンパが負担する荷重が大きくなっているこ とが原因である。このような場合には, 外付け装置を設置すること による加速度応答の増大にも留意する必要がある。

なお，本章の検討では入力地震動を特定しているため，外付け装 置を設置せずに主構造の剛性・耐力を適切に調整することでも層間 変形を一様化することは可能であると考えられる。しかし，その方 法で設計した建築物は，周期特性や位相特性の異なる地震動の入力

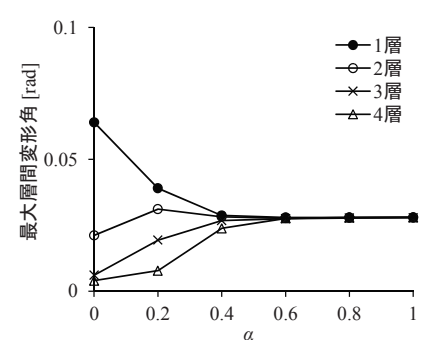

(a) 標準 0.5

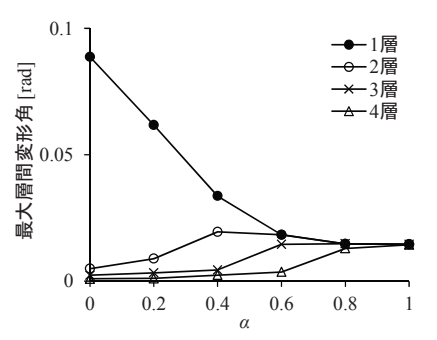

(b) 一様 0.5
図 $15 \alpha$ と最大層間変形角の関係

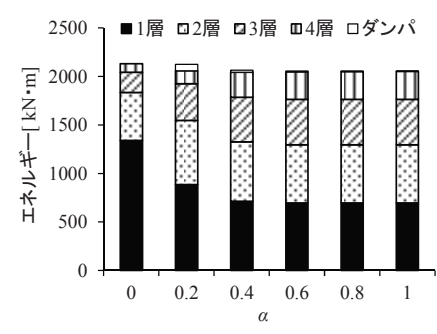

(a) 標準 0.5

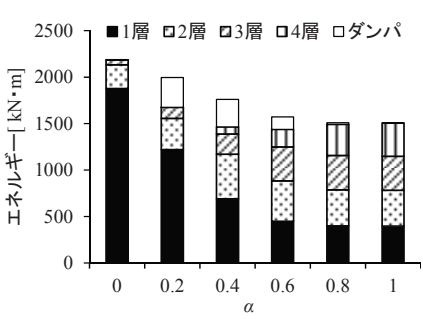

(b) 一様 0.5
図 $16 \alpha$ と各部の累積吸収エネルギーの関係

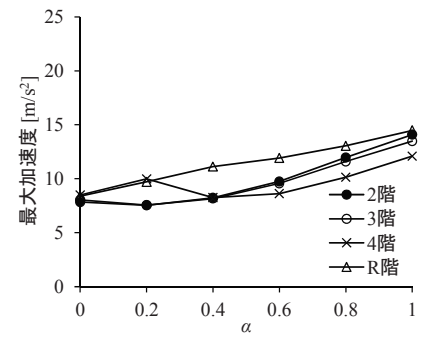

(a) 標準 0.5

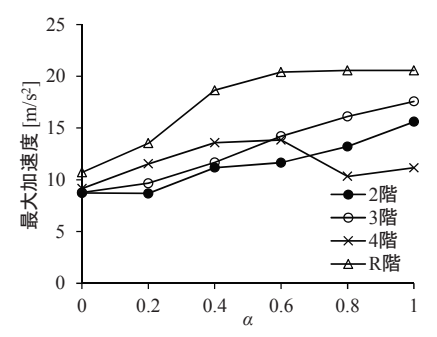

(b) 一様 0.5
図 $17 \alpha$ と最大応答加速度の関係

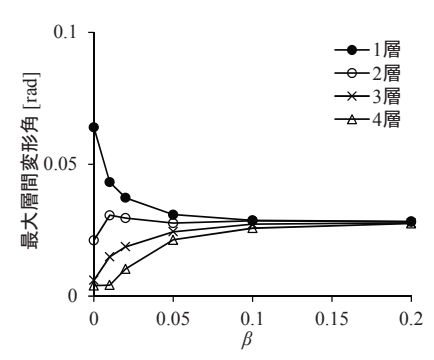

(a) 標準 0.5

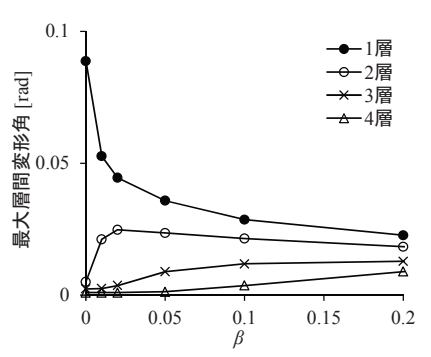

(b) 一様 0.5
図 $18 \beta$ と最大層間変形角の関係
に対しても層間変形が同一になるとは限らない。一方， $\alpha=1$ となる ように外付け装置を設置した建築物は, 入力地震動の最大加速度が 式(12)の計算に用いた加速度 $\ddot{x}_{0 \max }$ 以下であれば層間変形を同一に出 来ることが特長である。

\section{6. 平面フレームモデルによる時刻歴地震応答解析 \\ 6.1 解析モデル}

建築物に外付け装置を設置することによる応答低減と, ダンパの 抵抗力が周辺部材に与える影響等についてより詳細に検討寸るため, 平面フレームモデルを用いた時刻歴応答解析を行う。検討に用いる 建物モデルは，2007年に（独）防災科学技術研究所の実大 3 次元震 動破壊実験施設（E-ディフェンス）で実施された実大の 4 層鉄骨造 建築物 ${ }^{14)}$ の一つの構面をモデル化したものとした。図 19 には試験 体の梁伏図を, 図 20 にはモデル化の対象とした®通りの構面の軸組 図をそれぞれ示す。表 5 には，本章でのモデル化に必要な部材断面 を示す。部材の鋼種は梁材が SN400B, 柱材が BCR295 である。各 階の質量は, (A通りの構面が全体の $1 / 2$ を負担するとして, それぞ れ 2 階 $24.2 \mathrm{t}, 3$ 階 $24.1 \mathrm{t}, 4$ 階 $24.3 \mathrm{t}$, R 階 $32.2 \mathrm{t}$ とした。

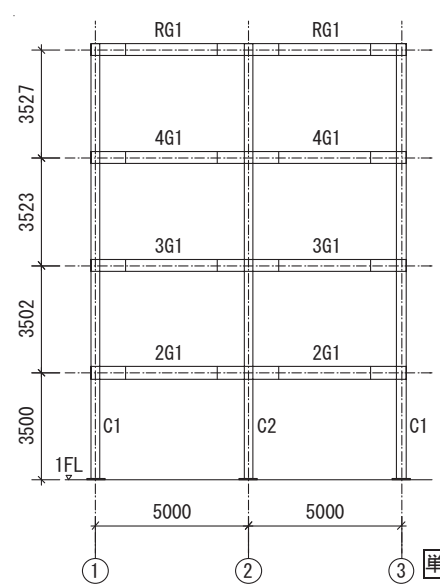

図 20 @通り構面の軸組図
表 5 柱梁部材の断面

\begin{tabular}{c|c}
\hline 記号 & 部材断面 \\
\hline RG1 & $H-346 \times 174 \times 6 \times 9$ \\
$4 \mathrm{G} 1$ & $\mathrm{H}-350 \times 175 \times 7 \times 11$ \\
$3 \mathrm{G} 1$ & $\mathrm{H}-396 \times 199 \times 7 \times 11$ \\
$2 \mathrm{G} 1$ & $\mathrm{H}-400 \times 200 \times 8 \times 13$ \\
$\mathrm{C} 1, \mathrm{C} 2$ & $\square-300 \times 300 \times 9$ \\
\hline
\end{tabular}

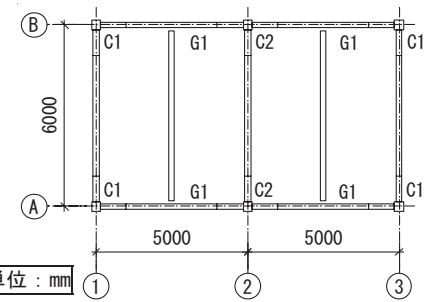

図 19 梁伏図
解析モデルにおいて, 柱梁部材の塑性化は材端集中ばねにより模 擬し, 材端ばねの復元力特性には骨格曲線が図 21 に示す 4 折れ線型 の Modified Ibarra-Krawinkler Deterioration（MIKD）モデル ${ }^{15)}$ を使 用した。 $M_{y}$ は降伏モーメント， $M_{c}$ は最大モーメント， $M_{r}$ は残留モ 一メントであり， $\theta_{p}$ と $\theta_{p c}$ は図中に示寸区間の回転角である。これら のパラメータの值は，部材の局部座屈による耐力低下を模擬するた め加藤らによって整理されている実験式 16) 17) を用いて決定し， $M_{r}$ は全ての部材で $0.4 M_{c}$ とした。解析ではパネルゾーンの変形および コンクリートスラブの影響は考慮していない。

外付け装置は, 設置位置の違いの影響について検討するため, 図 22 に示す Case1 と C ase 2 の 2 通りの配置で 3 基を設置した。フレー ムの水平部材の長さ $l$ は $2 \mathrm{~m}$, 柱とフレームのなす角 $\theta$ は $30^{\circ}$ とし, 部材の両端はピン接合とした。ダンパ部材には，5章と同様に完全 弾塑性型のばねを設置し摩擦ダンパを模擬した。ダンパの最大抵抗 力は，全層において柱が梁に先行して降伏するとした場合の各層の 最大耐力 $Q_{i \max }$ と $Q_{i \min }$ を式(12)に代入して得られる $F_{d i \mathrm{im}}$ と等しくし た。表 6 には，ダンパの最大抵抗力を示す。なお，本試験体は新耐 
震設計法に基づいて設計されている ${ }^{14)}$ ため, 全層において柱が先 行降伏寸る可能性は低く, 従って上記の計算によって求められる夕゙ ンパの最大抵抗力は層によっては過大となり得る。しかし，ここで の計算においてはダンパの必要抵抗力の上限值を求めることを意図 して全層柱降伏を仮定した。柱降伏を仮定した場合の各層の最大耐 力は全層において $585 \mathrm{kN}$ である。フレーム部材の断面は, ダンパの 最大抵抗力に対して座屈することなく現実的な断面として $\square-150 \times$ $150 \times 4.5$ とした場合と, フレームの変形が全く生じないと評価でき る程度に十分に大きな断面とした場合の 2 通りについて検討した。 また, Case1 については，5 章で行ったことと同様に $F_{\text {dilim }}$ に対する ダンパの最大抵抗力の比を $\alpha$ として $\alpha=0.2,0.3,0.4,0.6,0.8$ とした場 合についても解析を行い, ダンパの最大抵抗力の影響について検討 した。

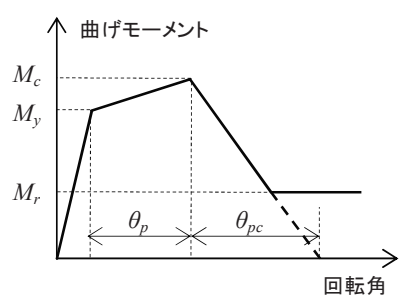

表 6 ダンパの最大抵抗力

図 21 MIKD モデルの骨格曲線

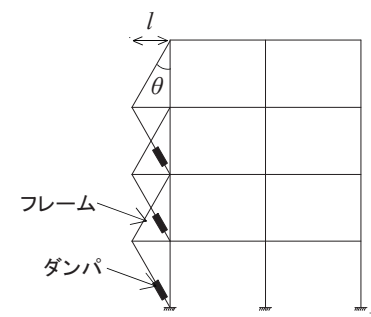

(a) Case 1

\begin{tabular}{c|c}
\hline 設置層 & 抵抗力 $[\mathrm{kN}]$ \\
\hline 3層 & 582 \\
2層 & 752 \\
1層 & 548 \\
\hline
\end{tabular}

図 22 外付け装置の設置位置

\section{2 解析方法}

全ての解析において, 柱梁部材の接続する節点に自重を作用させ る静的解析を最初に行い, その後静的解析の荷重条件および解析結 果を保持した状態で時刻歴応答解析を行った。時刻歴応答解析の数 值積分には Newmark $\beta$ 法 $(\beta=0.25)$ を用い, 刻み時間は $0.001 \mathrm{~s}$ とし た。大変形領域の応答を評価するため $P$ - $\Delta$ 効果も考慮した。解析に はOpenSees ${ }^{18)}$ を用いた。

入力地震動は, 外付け装置を設置しないモデルに対しては鷹取波 の原波と $60 \%$ に規準化した波の 2 波とし, 外付け装置を設置したモ デルに対しては鷹取波の原波のみとした。

\section{3 解析結果と考察}

外付け装置を設置しないモデルでは, 1 次固有周期は $0.80 \mathrm{~s}, 2$ 次 固有周期は $0.26 \mathrm{~s}$ となった。実験結果から評価された 1 次固有周期 は 0.74 0.78 s である ${ }^{14)}$ ので近い值となっている。鷹取波の $60 \%$ 規 準化波を入力して得られた全層の荷重変形履歴を図 23 に, 鷹取波の 原波を入力して得られた荷重変形履歴を図 24 にそれぞれ示す。縦軸 の荷重は, 各階の質量に応答加速度を乗じて求められる慣性力から 計算した層せん断力である。また図 25 には, 柱梁部材の塑性ヒンジ の発生箇所を示す。図中の○は降伏モーメントに達した箇所を,
は最大モーメントに達した箇所を示す。60\%規準化波の入力に対し ては特定の層に変形が集中寸ることは無く, また設計時の想定通り に梁が先行して降伏していることがわかる。一方で，原波の入力に 対しては 1 層のすべての柱頭と柱脚おいて最大モーメントに達して おり, 最終的に層崩壊に至っている。これらの解析結果は実験結果 19） 20）之同様の傾向であることから，解析モデルが概ね妥当である と判断できる。
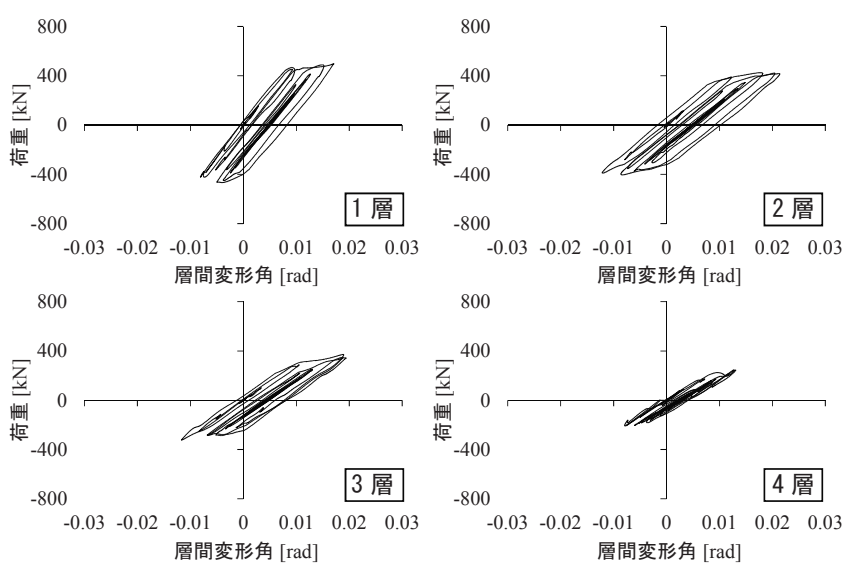

図 23 層の荷重変形履歴（外付け装置なし, 鷹取波 $60 \%$ )
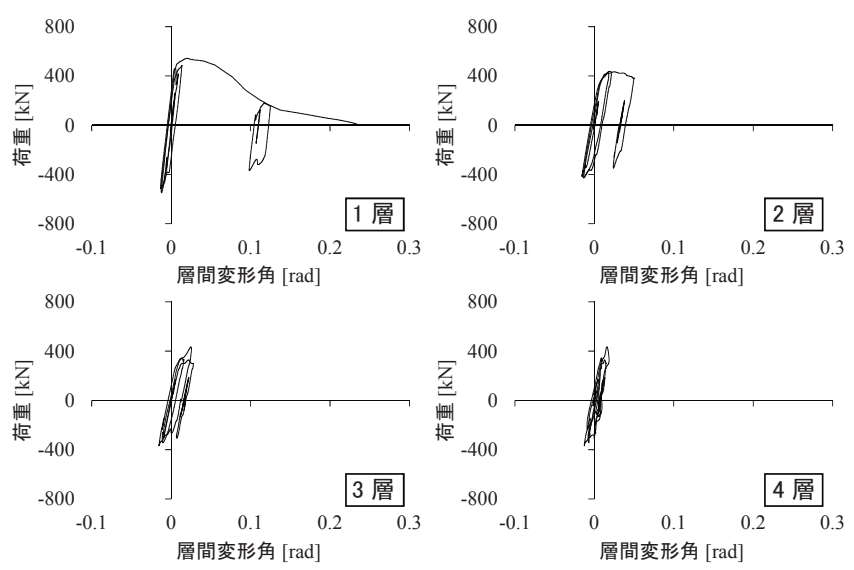

図 24 層の荷重変形履歴（外付け装置なし, 鷹取波 100\%)

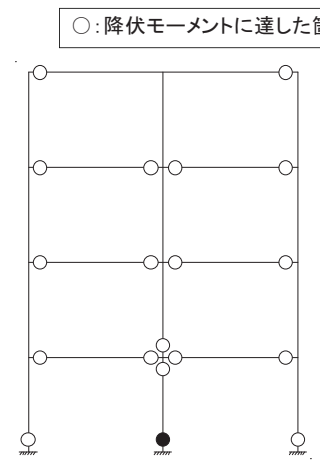

(a) 鷹取波 $60 \%$

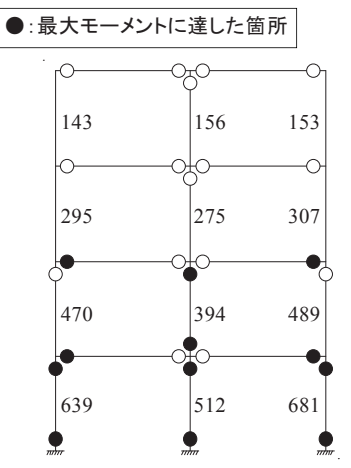

(b) 鷹取波 $100 \%$
図 25 塑性ヒンジの発生箇所（外付け装置なし）

外付け装置のフレーム部材の断面を $\square-150 \times 150 \times 4.5$ として, Case1 の配置でダンパを設置したモデルに鷹取波の原波を入力して 
得た各層の荷重変形履歴を図 26 に示寸。図27(a)には塑性ヒンジの 発生箇所を示す。外付け装置を設置しない場合と比較して, 全層で 同程度の層間変形が生じ建築物全体でエネルギーを吸収することで 1 層での層崩壊を抑制できている。また, 塑性ヒンジは梁に発生し ており, 過酷な地震動の入力に対しても設計時に意図した崩壊メ力 ニズムとなっている。なお，フレーム部材の断面を十分に大きくし た場合にも応答に差はなかったことから， $\square-150 \times 150 \times 4.5$ により 十分な剛性を確保出来ていることがわかる。

図 25(b) と図 27(a)の柱の横に示した数值は, 各柱に生じた最大軸 力（単位は $\mathrm{kN}$ ) である。両者を比較すると, 外付け装置を設置した 柱では軸力が増加していることがわかる。図27(b)には, Case2 の配 置で外付け装置を設置した場合の解析結果を示す。この場合には, 図 27(a) と比較して 2,3 層の (1)通りの柱軸力は減少し, 外付け装置を 設置した(3)通りの柱軸力は増加している。よって, 設計においては 外付け装置を設置する柱の軸力の増大にも配慮する必要がある。な お, Case1 と Case2 のいずれの場合も塑性ヒンジの発生箇所は同じ であり, また応答変形と応答加速度もほぼ同じであったことから, 応答低減効果に関しては両者に差はない。
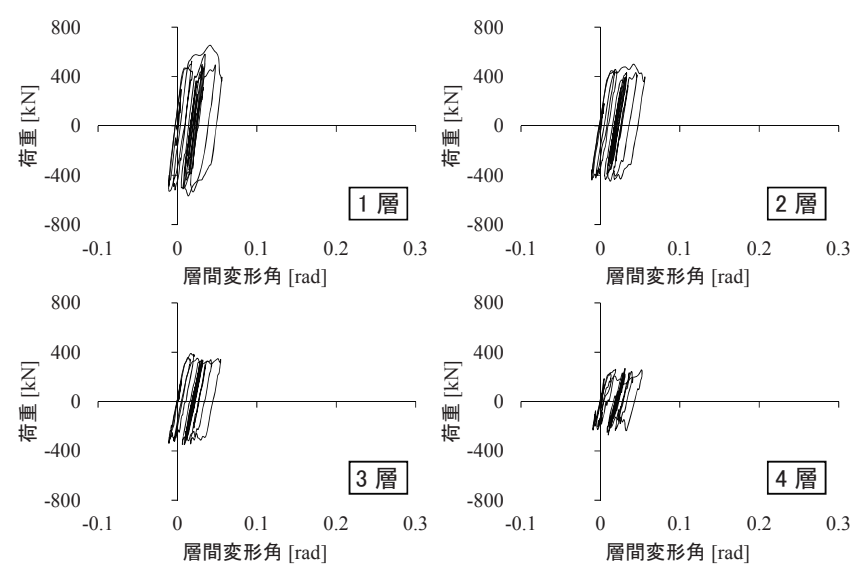

図 26 層の荷重変形履歴（外付け装置あり, Case1）

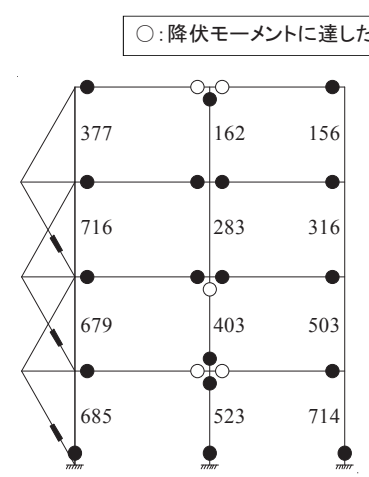

(a) Case1

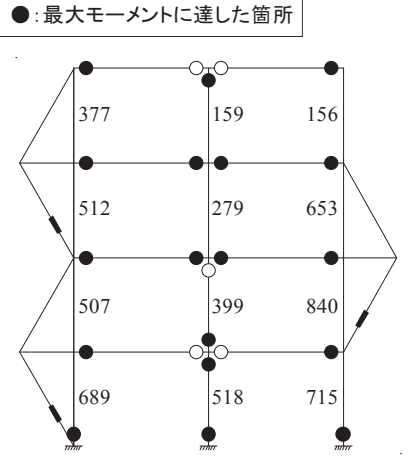

(b) Case2
図 27 塑性ヒンジの発生箇所（外付け装置あり）

表 7 には, Case1 のダンパに生じた最大軸力を示す。表 6 に示し たダンパの最大抵抗力の設計值と比較すると $50 \sim 60 \%$ 程度の值であ るが，これは 6.1 節で述べた通りダンパの最大抵抗力を計算する際 に全層で柱が梁に先行して降伏することを仮定したためである。

\section{表 7 ダンパの最大軸力}

\begin{tabular}{c|c}
\hline 層 & 最大軸力 $[\mathrm{kN}]$ \\
\hline 3 & 377.1 \\
2 & 398.5 \\
1 & 278.3 \\
\hline
\end{tabular}

図 28 には, $\alpha$ と各層の最大層間変形との関係を示す。 $\alpha=0$ は外付 け装置を設置しない場合である。 $\alpha \geqq 0.4$ では $\alpha$ の違いによる差はほ とんど認められないが， $\alpha<0.4$ では $\alpha$ の減少に伴って急激に 1 層の 層間変形が増大している。これは， $\alpha<0.4$ とした場合には， 1 層の層 間変形が柱の局部座屈が発生する変形にまで到達し著しい耐力低下 が生じているためである。 $\alpha=0.2$ では 1 層が完全に耐力を喪失し層 崩壊に至っている。このような現象は，5章で用いたような局部座 屈による急激な耐力低下を考慮しない解析モデルでは起こらないた め注意が必要である。図 29 には, $\alpha$ と各階の最大応答加速度の関係 を示す。外付け装置を設置した場合にも加速度の増加はほとんどな いことが認められる。

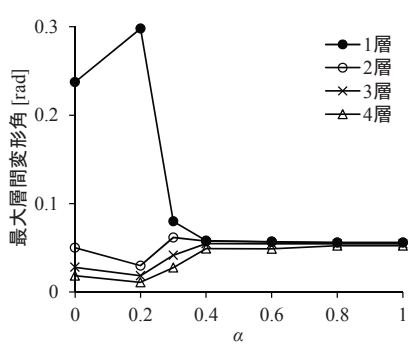

図 $28 \alpha$ と最大層間変形角の関係

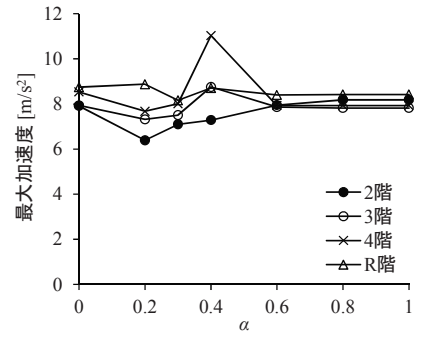

図 $29 \alpha$ と最大応答加速度の関係

\section{7. むすび}

本論では, 過酷な地震動の入力に対しても中低層建築物の層崩壊 を抑制する外付け式の層間変形制御装置を提案し, その力学特性と 有効性について解析的に検討した。以下に得られた知見を要約する。

・建築物の全層に外付け装置を設置し全層の層間変形を完全に等し くするためにダンパに要求される抵抗力の上限值は, 建築物各階 の質量と各層の最大耐力, および入力地震動の最大加速度から予 測できる。

・外付け装置のフレームが一定の剛性を有している場合, ダンパの 最大抵抗力を式(12)から計算される必要抵抗力の上限值 $F_{d i \mathrm{imm}}$ と同 じにすれば，地動加速度の最大值が式(12)の計算に用いた $\ddot{x}_{0 \max }$ 以 下である地震動に対しては全層の層間変形を同一に出来る。

・過酷な地震動の作用に対して特定層に変形が集中寸る建築物にお いても，外付け装置を設置することにより建築物全体で地震入力 エネルギーを吸収することが可能となり層崩壊を回避できる。

なお，主構造への外付け装置の取付けディテールの検討，ダンパ として粘性系や粘弾性系のダンパを用いる場合の応答性状に関する 検討，また振動実験による検討等については今後の課題である。

\section{謝辞}

本研究は, 2014 年度科学研究費補助金 若手研究 B 26820235 (代 
表者 宮津裕次）および 2014 年度科学研究費補助金 基盤 B 一般 26289195 (代表者 曽田五月也) より助成を受けて行いました。また, 早稲田大学理工学研究所に設けられたプロジェクト研究「各種建築 物の制振構造デザイン手法の高度化」(研究代表者: 曽田五月也) の 一部として行われたものであり，共同研究者の方々より貴重なご意 見を頂きました。ここに記して謝意を表します。

\section{参考文献}

1）曽田五月也, 堀込克哉: 過酷な地震動入力に対する建築物の備えーエネ ルギーに基づく地震動の過酷度指標の提案一, 日本建築学会大会学術講 演梗概集，構造 II , pp.717-718，2012.9

2）日本建築学会: 大振幅地震動と建築物の耐震性評価一巨大海溝型地震 . 内陸地震に備えて一，丸善出版，2013.9

3）秋山宏, 高橋誠：損傷分散型多層骨組の Ds 值, 日本建築学会論文報告 集，第 341 号，pp.54-61，1984.7

4）曽田五月也, 安田拓矢: リンク式オイルダンパの制振効果に関する研究, 日本建築学会大会学術講演梗概集, B-2, pp.821-822, 2007.7

5）曽田五月也，宮津裕次，宇平壮：リンク式オイルダンパによる建築物の 地震応答制御に関する研究 その 1 , 多層建築物の損傷集中抑制効果の 解析的検討, 日本建築学会大会学術講演梗概集, 構造 II , pp.893-894, 2013.8

6）曽田五月也, 宮津裕次：リンク式オイルダンパによる建築物の地震応答 制御に関する研究 その 2 , 偏心構造物のねじれ振動抑制効果の解析的 検討, 日本建築学会大会学術講演梗概集, 構造 II, pp.895-896, 2013.8

7）曽田五月也，宮津裕次，瀬戸純平，谷敬成：リンク式オイルダンパによ る建築物の地震応答制御に関する研究その 3 , 重量偏心した 1 層鉄骨 ラーメン架構の振動台実験による効果検証, 日本建築学会大会学術講演 梗概集，構造 II , pp.897-898，2013.8

8) Yuji Miyazu and Satsuya Soda : Seismic Response Control by Linked Oil Dampers, 13th World Conference on Seismic Isolation, Japan, USB, 2013.9

9）和田章, 内山裕太, 吉敷祥一, 伊藤浩資, 坂田弘安, 元結正次郎：ロッ キング壁による既存 RC 建物の耐震改修その 1 , 改修概要とダンパー 実験, 日本建築学会大会学術講演梗概集, C-2, pp.623-624, 2010.9

10）金田勝徳，木村祥裕，濱崎慎一，和田章：全層梁降伏型を目指した中低 層鉄骨ラーメン構造構築のための新しい柱脚機構の提案, 日本建築学会 構造系論文集, Vol.75 No.654, pp.1537-1546, 2010.8

11）宮津裕次, 曽田五月也 : 外付け式層間変形制御装置による建築物の地震 応答制御に関寸る研究 その 1 , 工法の概要と時刻歴地震応答解析によ る検討, 日本建築学会大会学術講演梗概集, 構造III, pp.437-438, 2014.9

12）曽田五月也, 宮津裕次, 宇平壮 : 外付け式層間変形制御装置による建築 物の地震応答制御に関寸る研究 その 2 , 小型 2 層木造軸組架構の強制 載荷実験による効果検証, 日本建築学会大会学術講演梗概集, 構造III, pp.439-440, 2014.9

13）松永裕樹，宮津裕次，曽田五月也：木造軸組耐力壁/非耐力壁の汎用乇 デル化手法に関する研究, 日本建築学会構造系論文集, Vol.74 No.639, pp.889-896,2009.5

14）吹田啓一郎，松岡祐一，山田哲，島田侑子，多田元英，笠井和彦：震動 台実験の概要と弾性応答特性一実大 4 層鉄骨造建物の完全崩壊実験 そ の 1 -, 日本建築学会構造系論文集, Vol.74 No.635, pp.157-166, 2009.1

15) Dimitrios G. Lignos and Helmut Krawinkler : Deterioration Modeling of Steel Components in Support of Collapse Prediction of Steel Moment Frames under Earthquake Loading, Journal of Structural Engineering, Vol.137, Issue 11, pp.1291-1302, 2011.11

16）加藤勉, 秋山宏, 帯洋一: 局部座屈を伴う $\mathrm{H}$ 形断面部材の変形, 日本 建築学会論文報告集，第 257 号, pp.49-58, 1977.7

17）加藤勉, 秋山宏, 北沢進：局部座屈を伴う箱型断面部材の変形, 日本建 築学会論文報告集，第 268 号, pp.71-76, 1978.6

18) Pacific Earthquake Engineering Research Center (PEER) : Open system for earthquake engineering simulation, http://opensees. berkeley.edu, 参照 2014.12.24

19）山田哲，吹田啓一郎，松岡祐一，島田侑子：震動台実験における弾塑性 応答特性と崩壊メカニズムの形成一実大 4 層鉄骨造建物の完全崩壊実 験 その 2-, 日本建築学会構造系論文集, Vol.74 No.644, pp.1851-1859,
2009.10

20）島田侑子, 吹田啓一郎, 山田哲, 松岡祐一, 多田元英, 大崎純, 笠井和 彦: 震動台実験における倒壊挙動一実大 4 層鉄骨造建物の完全崩壊実験 その 3-, 日本建築学会構造系論文集, Vol.75 No.653, pp.1351-1360, 2010.7 


\title{
SEISMIC RESPONSE CONTROL OF MID- AND LOW-RISE BUILDINGS USING EXTERNAL STORY DEFLECTION CONTROL DEVICES
}

\author{
Yuji MIYAZU* and Satsuya SODA**
}

\author{
* Assistant Prof., Graduate School of Engineering, Hiroshima Univ., Dr. Eng. \\ ** Prof., Dept. of Architecture, School of Creative Science and Engineering, Waseda Univ., Dr. Eng.
}

In large earthquakes lately occurred in Japan, such as the 1995 Kobe earthquake, the 2004 Niigata Earthquake and the 2011 Tohoku earthquake, many strong ground motions were recorded and some of their ground velocity were larger than that of the design earthquake ground motions. Although these ground motions are severe for buildings, it is important to prevent buildings from collapsing and to protect lives of people.

This paper proposes a seismic response control device which prevents mid- and low-rise buildings from collapsing at a specific story even when they are subjected to severe ground motions. The proposed device consists of the frame and the passive damper, which are mounted outside of the building. The damper used in this device is an ordinary passive damper, such as the friction damper or the oil damper; however, the method to reduce the seismic response is quite different from ordinary passive energy dissipation systems. When we install this device into the first and the second stories and use the friction damper, the resistance of the damper depends on the difference between the deflection of the first story and that of the second story; therefore, the damper works to equalize the deflection in each story.

In the first part of the paper, we constructed the analytical model of the proposed device using a mass-spring-damper system, and then derived the formula which predicts the upper limit resistance of the dampers to perfectly equalize the deflection of all the stories. The prediction formula demands the mass of all the floors, the maximum strength of all the stories of the building and the maximum acceleration of the input ground motion. Through the time history seismic response analysis of four-story steel buildings and two-story wooden houses, we confirmed the validity of the prediction formula.

In chapter 5, we conducted the time history seismic response analysis of some of the ordinary four-story steel structures with the proposed devices in order to clear the effectiveness of the device on reducing the maximum story deflection. We confirmed that if the relief resistance of the damper is the same as the upper limit resistance calculated by the abovementioned prediction formula, the devices perfectly equalize the deflection of all the stories and reduce the maximum story deflection. Even if the relief resistances of the dampers are approximately $50 \%$ of the upper limit resistance, the story deflections are reduced to a considerable extent without excessive increase of the acceleration response.

In the last part, conducted was the time history seismic response analysis of the four-story moment resistant steel frame. The steel frame model is the same as the full scale four-story building, which is designed according to the Japanese Building Standards Act, used in the shake table test at E-Defense in 2007. This building collapses at the first story under severe excitation because of local buckling at the column base of the first story. However, when we mount the devices on the building, the devices disperse the damages to all the stories and prevent the building from collapsing at a specific story. Since the response acceleration doesn't increase so much when we install the devices to the buildings, we concluded that the proposed structural system is effective to upgrade seismic performance of buildings. Furthermore, this device is also appropriate for seismic strengthening of existing buildings, since it can be mounted from the outside of the buildings. 